\title{
Ewe reproductive performance and growth rate of suckling-lambs on endophyte-infected perennial ryegrass pasture
}

\author{
R.H. WATSON ${ }^{1}$, R.G. KEOGH ${ }^{2}$ and M.F. MCDONALD ${ }^{1}$ \\ ${ }^{1}$ Institute of Veterinary, Animal and Biomedical Sciences, Massey University, Palmerston North \\ ${ }^{2}$ AgResearch,Grasslands Research Centre, Private Bag 11008, Palmerston North \\ ${ }^{2}$ keoghr@agresearch.cri.nz
}

\begin{abstract}
Two groups ( $\mathrm{n}=39)$ of Romney breeding ewes were maintained under the same grazing management on either endophyte-infected (E+) or endophytefree (E-) perennial ryegrass pasture for two years (1997-1998) following a one-year equilibration period. The ewes were naturally mated in March each year and ovulation rate at 1 st mating was measured, and conception and the number of lambs born and weaned were recorded. All ewes were weighed monthly and lamb growth rates were determined between birth and weaning. Mean mating date was delayed by 1.8 days $(\mathrm{P}<0.05)$ in the E+ ewes. There were no significant differences in any of the other reproductive parameters measured in either year. Grazing endophyte-infected pasture had a significant $(\mathrm{P}<0.001)$ negative effect on ewe liveweight, which appeared to be a result of reduced feed intake by the E+ ewes. Growth rate of twin- and single-lambs suckling ewes grazing $\mathrm{E}+$ pasture were significantly $(\mathrm{P}<0.01)$ reduced in the second year of the trial but not in the first year. Differences in lamb growth rate may have been due to differences in ewe milk production. Ergovaline and lolitrem B levels in the E+ pasture were significantly higher in 1998 than they had been in 1997. Ewe and lamb performance in relation to endophyte toxin levels in the pasture is also discussed.
\end{abstract}

Keywords: endophyte, ewe, lamb growth rate, Neotyphodium lolii, perennial ryegrass, reproductive performance

\section{Introduction}

The reproductive performance of many New Zealand ewe flocks is well below their potential (Knight 1990). There are many possible causes of this reduced reproductive performance such as poor ewe condition at mating, trace element deficiencies and starvation/ exposure in new-born lambs. Recently there has been much interest in the deleterious effects of mycotoxins produced by some species of saprophytic fungi present in New Zealand pastures (Smith 1998).
Perennial ryegrass is the most important and widely grown pasture grass species in New Zealand. More than $90 \%$ of these pastures are infected with the endophyte fungus Neotyphodium lolii. This association between fungus and grass is best known for conferring resistance to attack by Argentine stem weevil by production of the toxin peramine. It is also known for causing the neuromuscular disorder ryegrass staggers in livestock by producing the toxin lolitrem B (Blythe et al. 1993).

It has recently been found that ryegrass infected with $N$. lolii produces several other major toxins similar to those found in endophyte-infected (E+) tall fescue pastures (Rowan et al. 1990). These toxins have a wide range of physiological activity in many species of livestock (Oliver 1997).

One of the more important of these toxins is the ergopeptine-alkaloid ergovaline. Ergovaline is considered the primary toxin involved in much of the poor animal performance associated with grazing endophyteinfected pasture. Reduced reproductive performance is a major contributing factor to the poor performance of animals grazing E+ tall fescue. Ewes grazing E+ tall fescue pasture containing ergovaline suffered from reduced fertility (Kramer et al. 1999). Ovulation rate differences in that trial were not due to liveweight or liveweight change differences in the ewes, and were most likely due to the direct effects of endophyte toxins on the reproductive system. Ergovaline has been found to disrupt many of the endocrine functions associated with reproduction (Oliver 1997).

Therefore, ewes grazing endophyte-infected ryegrass pastures that contain ergovaline may have reduced reproductive performance. The widespread presence of endophyte in pastures may be responsible for some of the poor reproductive performance of many New Zealand ewe flocks.

The aims of this study were to determine the effects of grazing endophyte-infected ryegrass pasture on reproductive performance of the ewe and the growth rate of suckling lambs.

\section{Materials and methods}

\section{Animals}

Rising two-tooth Romney ewes, of a similar genetic background, were obtained from a Northland ewe flock 
and transported to AgResearch Aorangi Lowland Research (AOR) Station in the Manawatu on 11 January 1996. The ewes grazed a brassica crop until 11 March 1996 when all ewes were ear-tagged, and 78 ewes were randomly selected and allocated to two treatment groups with the same average liveweight. Ten spare ewes were allocated to each group as replacements for animals in the treatment groups if required.

Two-tooth ewes were used to enable the lifetime reproductive performance of the ewes to be measured.

\section{Treatment pastures}

Six 0.5-ha plots were fenced and sown on 8 November 1995 at AOR on Kairanga silt loam. The trial area had a history of lotus (Lotus pedunculatus) and cocksfoot (Dactylis glomerata) pastures.

Three replicate plots were sown in Nui perennial ryegrass seed $(33 \mathrm{~kg} / \mathrm{ha})$ infected with high levels (reputed $88 \%$ ) of endophyte $(\mathrm{E}+)$. The remaining three replicate plots were sown in Nui perennial ryegrass seed $(40 \mathrm{~kg} / \mathrm{ha}$ ) which was free (reputed $0 \%)$ of endophyte infection (E-). The pasture replicates were arranged in a complete randomised design across the trial area. On 4 December 1995 the newly sown trial area was sprayed with 2.5 l/ha MCPB, 2.5 l/ha 2-45D, and 5 1/ha MCPA to remove any non-grass species.

In October 1996 a further two 0.5-ha plots were sown in Nui E+ and two in Nui E- at a seeding rate of $25 \mathrm{~kg} / \mathrm{ha}$.

\section{Ewe-flock management}

Each group of ewes was allocated to one of the two pasture treatments and was used to graze their respective pastures from the end of March 1996 to January 1997 as a pre-trial preparation. The spare ewes were grazed on adjacent E+ or E- pastures.

All trial and spare ewes were mated in April 1996 and lambed on their respective areas in September. The lambs were weaned in November 1996 and removed from the trial.

By the end of 1996 the ewes grazing the $\mathrm{E}+$ pasture were significantly lighter than the E- ewes, so on 10 January 1997 spare ewes were used to replace some ewes in the treatment groups so that the groups were the same average liveweight at mating in 1997. The trial period began at mating in 1997 and from this time the same ewes were used in each group throughout the 2year trial period, and were replaced with spare ewes only in the case of death.

In 1997 and 1998 the groups of ewes were rotationally grazed with the same pasture allowance, from lamb docking in late September till the end of mating in April. The extra plots sown in 1996 were used to provide additional feed to groups that required it during rotational grazing and any surplus pasture caused by differences in feed intake between the treatment groups was accumulated on these extra plots and grazed by the spare ewes. The spare ewes were also used to graze the plots to maintain uniformity between the E+ and Epastures. Mature seedhead and long ungrazed areas of the pastures were removed by a forage harvester in late summer to maintain pasture quality, with thorough cleaning of the machinery between plots to ensure no seed contamination.

On 1 March each year a Suffolk ram fitted with a mating harness was introduced to each group of ewes. The rams were rotated between the groups weekly for two oestrous cycles and then removed. From the end of mating, each group of ewes was set stocked over treatment plots throughout gestation and lambing.

Each year the ewes were vaccinated with Multiline ${ }^{\mathrm{TM}}$ 5 in 1 against clostridial diseases, and crutched two weeks before the start of lambing. In 1997, lambs remained with the ewes until weaning at the beginning of November (11 weeks from start of lambing) at which point they were removed from the trial. In 1998, lambs were kept with the ewes 6 weeks longer and weaned in mid-December (17 weeks from start of lambing) so that growth rates could be monitored further.

\section{Animal measurements}

Mating date was recorded for each ewe. After the $1^{\text {st }}$ oestrous cycle, the crayon colour was changed and ewes that returned to oestrus were recorded. The ovaries of each ewe were examined by laparoscopy between days 3 and 7 after first mating to measure ovulation rate (corpora lutea/ewe). All ewes were examined by ultrasonography 90 days after the start of mating to measure the number of foetuses carried per ewe.

After each ewe lambed, the lambs were tagged and the number of lambs born per ewe, birth date and birth weight were recorded. In 1997, lambs were weighed weekly for the first six weeks of life. In 1998, lambs were weighed every $2-3$ weeks from birth to weaning (17 weeks).

Each group of ewes was weighed monthly throughout the year.

\section{Pasture measurements}

Three quadrat pasture cuts $(20 \mathrm{~cm} \times 50 \mathrm{~cm})$ were taken monthly from under exclusion cages, and grazed areas in each plot. Each pasture sample was freeze-dried and weighed to determine pre- and post-grazing herbage mass and daily pasture growth rate.

A sub-sample of each pasture cut was dissected into ryegrass blade and sheath, and non-ryegrass species. The ryegrass components were ground and analysed for lolitrem B and ergovaline concentration as previously 
described by Barker et al. (1993). A further pasture sub-sample was ground for nutritional analysis.

\section{Statistical analysis}

All statistical analyses were carried out using Graphpad Prism ${ }^{\mathrm{TM}} 3.0$ computer software: 10855 Sorrento Valley Rd \#203, San Diego, CA 92121 USA.

Ovulation and conception rate, mating date, lambs carried per ewe at scanning, and lambing percentage data were analysed by chi-squared test.

Ewe liveweight data were analysed by analysis of variance (ANOVA).

Lamb growth-rate data were analysed by fitting a generalised linear model to determine sources of variation due to treatment (endophyte), time (week of weighing) and treatment $\mathrm{X}$ time interactions.

Pasture growth rate, nutritional parameters, pre- and post-grazing herbage mass and endophyte toxin level data were analysed by ANOVA.

\section{Results}

\section{Pasture composition}

No differences in pasture composition were detected between treatments at any time in the trial. Grasses other than ryegrass made up $35 \%$ of total green herbage in mid-spring, and were much lower at all other times. Legumes were never a significant component.

\section{Reproductive performance}

The E+ ewes mean mating date was 1.8 days later than the $\mathrm{E}-$ ewes $(\mathrm{P}<0.05)$ in both 1997 and 1998. Lambing started around 24 July and was completed by 10 September in each year. There were no significant differences in any other of the reproductive parameters measured between the E+ or E- ewes (Table 1).

\section{Ewe liveweight}

At the start of mating in 1997 there was no significant difference in liveweight between the E+ and E- ewes (54.7 \pm 0.8 $\mathrm{kg}$ and $55.5 \pm 0.7 \mathrm{~kg}$ respectively). The mean liveweights of the two groups did not change significantly during the mating period (Figure 1). Between the end of mating and July 1997 the E+ ewes put on significantly less weight $(\mathrm{P}<0.001)$ than the $\mathrm{E}$ ewes $(26 \pm 1 \mathrm{~g} / \mathrm{h} / \mathrm{d}$ vs $40 \pm 1 \mathrm{~g} / \mathrm{h} / \mathrm{d})$. By July 1997 the E+ ewes were significantly $(\mathrm{P}<0.001)$ lighter than the E- ewes. There was no significant difference in prelambing liveweight of single-bearing ewes between the $\mathrm{E}+$ and E- groups $(60.1 \pm 1.1 \mathrm{~kg}$ and $62.0 \pm 1.2 \mathrm{~kg}$ for the E+ and E- ewes respectively). However, twinbearing E+ ewes were significantly lighter than the Etwin-bearing ewes $(60.0 \pm 1.2 \mathrm{~kg}$ and $65.7 \pm 0.9 \mathrm{~kg}$ for the E+ and E- ewes respectively). During lambing (July 24-Sep 10) the E+ ewes lost $4.4 \mathrm{~kg}$ on average whereas the E- ewes were on average $0.5 \mathrm{~kg}$ heavier at the end of lambing.

The E- ewes remained an average $6.2 \pm 0.7 \mathrm{~kg}$ heavier $(\mathrm{P}<0.001)$ from September 1997 until January 1998 , during which period the average liveweight of the groups did not alter significantly.

At the start of mating in 1998 the E+ ewes were significantly $(\mathrm{P}<0.001)$ lighter than the E- ewes $(59.5$ $\pm 1.3 \mathrm{~kg}$ vs $64.9 \pm 1.1 \mathrm{~kg}$ for $\mathrm{E}+$ and $\mathrm{E}$ - groups respectively). Between January and April 1998 the E-
Figure 1 Mean $( \pm S E M)$ liveweight of ewes grazing either endophyte-infected $(E+)$, or endophyte-free (E-) perennial ryegrass during 1997 and 1998.

Table 1 Ovulation rate, lambs carried per 100 ewes at scanning, $\%$ of ewes returning to oestrous, $\%$ of ewes dry at scanning, lambs born per 100 ewes and lambs weaned per 100 ewes in groups of ewes grazing either endophyte-infected or endophyte-free.

\begin{tabular}{|c|c|c|c|c|}
\hline & \multicolumn{2}{|c|}{------------------- 1997 ------------------- } & \multicolumn{2}{|c|}{ 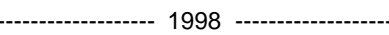 } \\
\hline & $\mathrm{E}_{+}$ & E- & $E_{+}$ & E- \\
\hline Ovulation rate & $1.67 \pm 0.08$ & $1.63 \pm 0.08$ & $1.66 \pm 0.08$ & $1.81 \pm 0.08$ \\
\hline Number of ewes that returned to oestrus & 8 & 11 & 8 & 9 \\
\hline Scanning \% (includes dry ewes) & $146 \pm 10$ & $163 \pm 7$ & $141 \pm 10$ & $136 \pm 9$ \\
\hline Number of ewes dry at scanning & 2 & 1 & 2 & 4 \\
\hline Lambing \% (born per ewes mated) & $145 \pm 10$ & $161 \pm 9$ & $141 \pm 10$ & $136 \pm 9$ \\
\hline Lambing \% (weaned per ewes mated) & $104 \pm 11$ & $122 \pm 10$ & $117 \pm 10$ & $122 \pm 9$ \\
\hline
\end{tabular}


ewes lost on average $2.2 \pm 0.6 \mathrm{~kg}$, whereas the E+ ewes remained at the same weight from January to March and gained an average of $2.7 \pm 0.5 \mathrm{~kg}$ between March and April, so that in April there was no significant difference in liveweight between the two treatment groups. By the end of mating the E- ewes had regained the weight lost between January and March and were again significantly $(\mathrm{P}<0.001)$ heavier than the E+ ewes $(65.9 \pm 0.9 \mathrm{~kg}$ and 62.5 $\pm 1.2 \mathrm{~kg}$ for $\mathrm{E}-$ and $\mathrm{E}+$ groups respectively). The pre-lambing (July) ewe liveweights were significantly $(\mathrm{P}<0.05)$ lower in both the single $(56.3 \pm 1.9 \mathrm{~kg})$ and twin-bearing $(59.3 \pm 2.1 \mathrm{~kg})$ E+ ewes than they were for the single $(64.8 \pm 1.9 \mathrm{~kg})$ and twin-bearing $(65.7 \pm 2.2 \mathrm{~kg}) \mathrm{E}$ ewes. Between May 1998 and December 1998 the average liveweight of ewes in the E+ group was $6.2 \pm 0.7 \mathrm{~kg}$ lighter $(\mathrm{P}<0.001)$ than the E- group.

\section{Lamb birth weight}

There were no significant differences in the birth weight of single or twin lambs between the E+ and E- ewes in either 1997 or 1998 (Table 2). Single lambs were significantly $(\mathrm{P}<0.05)$ heavier than twin lambs in both years. Lamb sex had no significant effect on birth weight in either 1997 or 1998.

\section{Lamb growth rate}

1997

In 1997 there was no significant difference in daily growth rate from birth to six weeks old between twin lambs born on the $\mathrm{E}+(\mathrm{n}=20)$ or $\mathrm{E}$ $(n=28)$ treatments. Daily growth rate over this sixweek period was significantly $(\mathrm{P}<0.001)$ greater in the E+ single lambs $(\mathrm{n}=11)(400 \pm 13 \mathrm{~g} / \mathrm{h} / \mathrm{d})$ than the E- single lambs $(\mathrm{n}=9)(317 \pm 11 \mathrm{~g} / \mathrm{h} / \mathrm{d})$ (Figure 2). There was no significant effect of time (weeks) or interaction between endophyte and time in any group of lambs. The liveweights of the single lambs at six weeks old were $22.2 \pm 1.0 \mathrm{~kg}$ and $18.1 \pm 0.6 \mathrm{~kg}$ $(\mathrm{P}<0.01)$ for the $\mathrm{E}+$ and $\mathrm{E}-$ treatments respectively. There was no difference in the liveweights at six weeks old of the twin lambs in the two groups (15.0 \pm $0.6 \mathrm{~kg}$ and $14.4 \pm 0.5 \mathrm{~kg}$ for the E+ and E- groups respectively). There was no significant effect of sex on lamb growth rate in 1997 or 1998.
Table 2 Mean $( \pm$ SEM) birth weights $(\mathrm{kg})$ of single and twin lambs born to ewes grazing either $\mathrm{E}+$ or $\mathrm{E}$ - ryegrass.

\begin{tabular}{ccccc}
\hline Year & E+ Singles & E- Singles & E+ Twins & E-Twins \\
\hline 1997 & $6.07 \pm 0.31$ & $5.91 \pm 0.21$ & $4.59 \pm 0.12$ & $4.52 \pm 0.11$ \\
1998 & $5.48 \pm 0.19$ & $5.52 \pm 0.24$ & $4.55 \pm 0.16$ & $4.59 \pm 0.14$ \\
\hline
\end{tabular}

Figure 21997 mean ( \pm SEM) daily growth rates of twin and single lambs born to ewes grazing either $\mathrm{E}+$ or $\mathrm{E}$ - ryegrass.

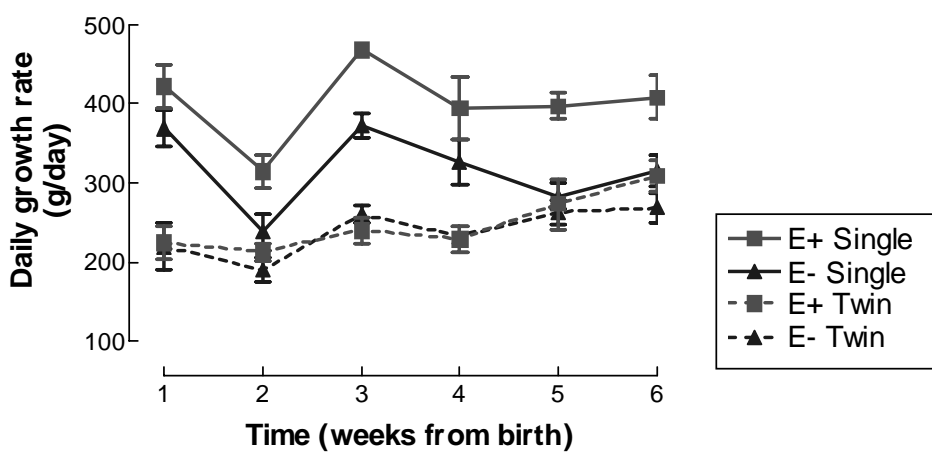

Figure 31998 mean $( \pm$ SEM) daily growth rates of twin and single lambs born to ewes grazing either $\mathrm{E}+$ or $\mathrm{E}$ - ryegrass.

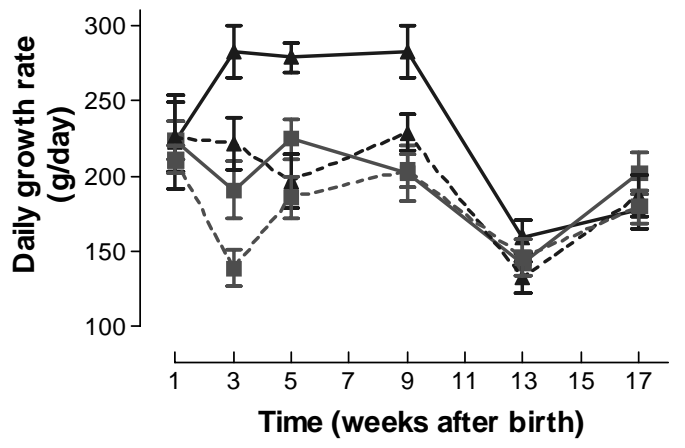

1998

In 1998 twin lambs born on the $\mathrm{E}+$ treatment $(\mathrm{n}=26)$ had significantly $(\mathrm{P}<0.05)$ lower daily growth rates from birth to three weeks old, than twin lambs born on the Etreatment (n=26) (Figure 3) $(139 \pm 12 \mathrm{~g} / \mathrm{h} / \mathrm{d}$ vs $222 \pm 17$ $\mathrm{g} / \mathrm{h} / \mathrm{d}$ for the $\mathrm{E}+$ and $\mathrm{E}$ - treatments respectively). Growth rates of twin lambs between three weeks of age and seventeen weeks (weaning) were not significantly different between the treatment groups, however, E+ twin lambs $(30.1 \pm 0.7 \mathrm{~kg})$ were significantly $(\mathrm{P}<0.05)$ lighter at seventeen weeks (weaning) than E- twin lambs $(33.6 \pm 1.2 \mathrm{~kg})$.

Single lambs born on the E+ treatment $(n=15)$ had significantly lower $(\mathrm{P}<0.01)$ daily growth rates from birth to nine weeks than the single lambs born on the E- treatment $(n=16)$ (Figure 3). During this period the 
E- single lambs were growing an average $76 \pm 11 \mathrm{~g} / \mathrm{h} / \mathrm{d}$ more than the $\mathrm{E}+$ single lambs. There was no significant difference in the daily growth rate of single lambs from weeks nine to seventeen (weaning) between the $\mathrm{E}+$ and E- treatments. However, the E- single lambs $(37.8 \pm$ $1.2 \mathrm{~kg})$ were significantly $(\mathrm{P}<0.01)$ heavier than the E+ single lambs $(33.7 \pm 1.0 \mathrm{~kg})$ at weaning. There was no significant effect of time (weeks) or interaction between endophyte and time.

\section{Pasture growth rate and nutritional analysis}

No significant differences in daily pasture growth rate between the $\mathrm{E}+$ and $\mathrm{E}$ - pastures were measured at any time during the trial. Additionally, there were no significant differences in pasture dry matter, protein, lipid, ash, acid detergent fibre, neutral detergent fibre, dietary cation-anion difference, organic matter digestibility or metabolisable energy between the E+ and $\mathrm{E}$ - ryegrass pasture at any time of the year.

\section{Post-grazing residues}

There were no significant differences in post grazing herbage mass between the E+ and E- groups during spring and summer in 1997 or 1998 (Table 3). During autumn 1997 and 1998, ewes grazing the E- pasture left significantly $(\mathrm{P}<0.001)$ lower post-grazing herbage mass than ewes grazing the $\mathrm{E}+$ pasture. The same trend was indicated in the summer data.

\section{Pasture ergovaline and Lolitrem $B$ levels}

There was a significant $(\mathrm{P}<0.001)$ effect of season on ergovaline levels in the ryegrass leaf blade and ryegrass leaf sheath components of the E+ pasture. Ergovaline levels (Figure 4) were significantly higher during late spring, summer and autumn
(November to April) in the blade and sheath than levels in the winter (May to September). This seasonal pattern was similar in both years.

During periods of increased ergovaline production, levels were more than two times higher $(\mathrm{P}<0.001)$ in the sheath than in the blade in both 1997 and 1998. No ergovaline was detected in the E- pasture at any time.

Lolitrem B levels (Figure 5) in the E+ pasture followed similar (significant, $\mathrm{P}<0.001$ ) seasonal patterns to ergovaline, although the rise in summer was later and more sharply defined. Lolitrem B levels in the sheath were generally 3 to 4 times higher than in the blade during autumn. Lolitrem B levels were very low or nondetectable during the winter in both blade and sheath.

Ergovaline and lolitrem B levels were significantly $(\mathrm{P}<0.05)$ higher in the blade and sheath during mating 1998 than during mating 1997.

Figure 4 Mean $( \pm$ SEM) ergovaline concentrations in the ryegrass leaf blade and leaf sheath components of the E+ pasture during 1997 and 1998.

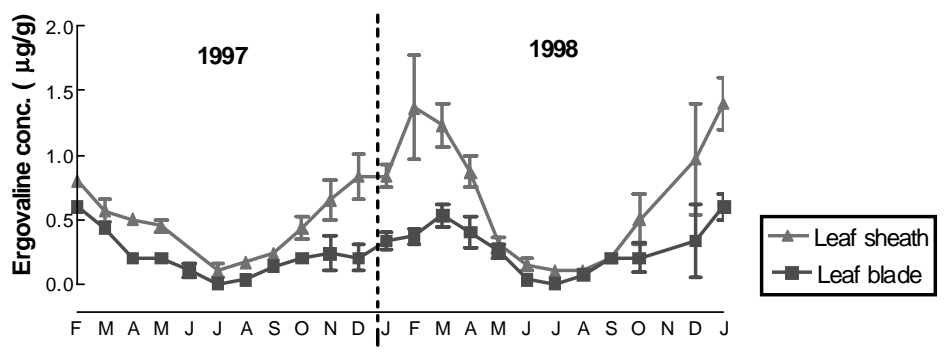

Figure 5 Mean $( \pm$ SEM) Lolitrem $B$ concentrations in the ryegrass leaf blade and leaf sheath components of the E+ pasture during 1997 and 1998.

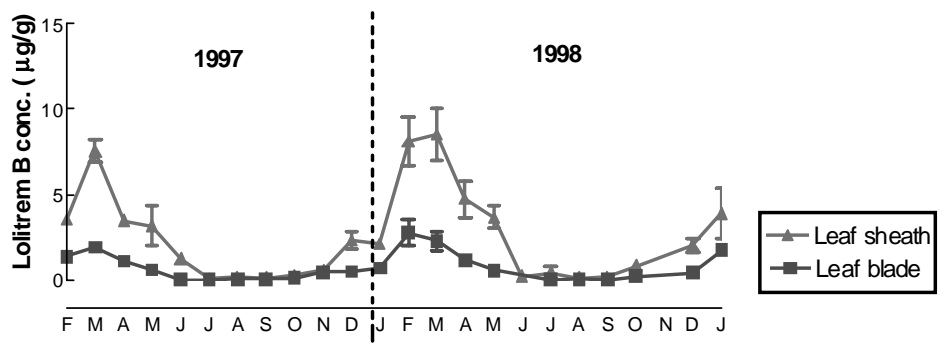

Table 3 Mean ( \pm SEM) pre-grazing pasture allowance and post-grazing residues of the E+ and E- groups in spring, summer and autumn 1997 and 1998.

\begin{tabular}{|c|c|c|c|c|c|c|}
\hline \multirow[b]{2}{*}{ Season } & \multicolumn{2}{|c|}{$\begin{array}{c}\text { Pasture offered } \\
(\mathrm{kg} \mathrm{DM} / \mathrm{ha})\end{array}$} & \multicolumn{4}{|c|}{ Post-grazing residue } \\
\hline & 1997 & 1998 & $E_{+}$ & E- & $E_{+}$ & E- \\
\hline Spring & $3710 \pm 156$ & $3269 \pm 213$ & $1228 \pm 120$ & $1374 \pm 136$ & $1467 \pm 93$ & $1704 \pm 126$ \\
\hline Summer & $3859 \pm 128$ & $3824 \pm 146$ & $2348 \pm 145$ & $1959 \pm 265$ & $2447 \pm 131$ & $2088 \pm 237$ \\
\hline Autumn & $2668 \pm 238$ & $2223 \pm 153$ & $1425 \pm 125$ & $1077 \pm 69^{a}$ & $1793 \pm 115$ & $870 \pm 55^{a}$ \\
\hline
\end{tabular}

NB: Mean post-grazing residues marked a differ significantly $(\mathrm{P}<0.01)$ between treatments. 


\section{Discussion}

\section{Reproductive performance}

Grazing endophyte-infected perennial ryegrass pastures did not directly affect ewe fertility in this trial. Before the equilibration period during 1996 the ewes were raised from birth on E+ dominant pastures in Northland and any carryover effects of this on ewe production can not be determined in this trial. While the equilibration period may not have eliminated it should have reduced carryover effects of E+ pasture in the E- group.

Grazing endophyte-infected tall fescue has been shown to reduce ovulation rate in ewes (Kramer et al. 1999), however, it would appear that the effects of grazing endophyte-infected perennial ryegrass are not as severe. This is likely to be due to the comparatively lower levels of ergovaline in perennial ryegrass than those found in E+ tall fescue. Mean ergovaline levels in the ryegrass leaf blade during mating in this trial were $0.3 \mathrm{ppm}$ and $0.5 \mathrm{ppm}$ for 1997 and 1998 respectively whereas levels of ergovaline in the tall fescue pastures in the trial by Kramer et al. (1999) were more than $3 \mathrm{ppm}$.

Ovulation rate was not significantly affected in this trial, where herbage ergovaline concentrations did not greatly exceed $1 \mathrm{ppm}$ (1.4 ppm in leaf sheath). E+ ryegrass pastures may produce ergovaline levels above 2 ppm (G.A. Lane, pers. comm.) and extreme levels up to $27 \mathrm{ppm}$ have been measured in natural associations of endophyte-infected perennial ryegrass under glasshouse conditions (Lane et al. 1997). It is likely that ewes grazing pastures where ergovaline levels exceed $2 \mathrm{ppm}$ would suffer a reduction in reproductive performance.

The 1.8-day delay in mating date in the E+ ewes is consistent with observations made by Eerens et al. (1994) who found a 4.5-day delay in parturition date in ewes grazing E+ pasture compared with E-pasture, and this was associated with a delay in mating. This delay is probably of little significance in terms of ewe productivity. However, any factor that contributes to a delay in mating is undesirable for farmers who wish to produce more lambs from their ewe flock in early spring. The causes of this delay are unclear at present.

\section{Ewe liveweight}

During the two-year trial period, the E+ ewes were usually lighter than the E- ewes. This difference in ewe liveweight occurred despite both groups receiving the same grazing management and herbage allowance. This suggests that the weight differences may have been a result of reduced voluntary feed intake in the E+ ewes (indicated by the higher post-grazing residues) rather than any differences in the pasture or management.
Between January and March 1998 the E- ewes lost an average of $5.2 \pm 0.6 \mathrm{~kg}$. This was due to a reduction in the amount of E- pasture available during this time. Although there was no difference in pasture growth rate between the E+ and E- pastures during this time, the Eewes grazed their pastures more closely, and therefore the E- pasture supply was used up more quickly.

The depression of weight gains in sheep grazing endophyte-infected perennial ryegrass pasture has been observed by Fletcher (1999) who attributed this in part to differences in feed intake.

It is likely that E+ pasture is less acceptable to sheep than E- pasture, which appears to be expressed as a reluctance to graze the lower portion of the ryegrass plant such as the pseudostem. This reluctance may be due to toxin levels being significantly higher in the leaf sheath that makes up the pseudostem than they are in the leaf blade. Edwards et al. (1993) showed that, although there were no differences in grazing time of hoggets grazing $\mathrm{E}+$ and $\mathrm{E}$ - perennial ryegrass pasture, less E+ was consumed and this was due to a reluctance to graze the $\mathrm{E}+$ pseudostem horizon.

The reluctance to graze the pseudostem horizon was also observed in this trial. This was particularly evident in the autumn when the E+ ewes left significantly higher post-grazing herbage mass than the E- ewes despite the same pre-grazing mass of similar quality pasture (see Table 3).

Ewe liveweight and liveweight gain are important determinants of reproductive performance. There are strong associations between liveweight of ewes at mating and the subsequent number of lambs born.

It is likely that the long-term effects of grazing endophyte-infected pasture on ewe liveweights, particularly at critical times such as before mating, will result in reduced reproductive performance.

Determining differences in ovulation rate between ewes grazing either E+ or E- may have been confounded in this trial by the significant differences in pre-mating weight change between the E+ and E- group in 1998.

\section{Lamb growth rate}

The growth rate of single suckling-lambs during the first six weeks of life in 1997 was greater in the E+ than in the E- group and there was no difference in the growth rate of twin lambs. The growth rate of both single and twin suckling-lambs during the first nine weeks of life was significantly lower in the E+ group than in the E- group in 1998.

The effects of grazing E+ pasture on the growth rate of suckling lambs were variable and inconsistent, which was in part due to the small number of lambs in each group. However, data collected on lamb growth rate in 1998 suggested that endophyte does have a negative 
effect on the growth rate of suckling lambs. The reasons for this depression in growth rate were unclear but may be due to lower milk production by the E+ ewes. There could also have been differences in the relative amount of herbage consumed by the E+ and E- lambs during the first six weeks of life.

The 1998 results are consistent with those of Eerens et al. (1994) who also found that lambs suckling ewes that grazed E+ pasture had lower growth rates than lambs suckling ewes grazing E- pasture.

In 1997 the growth rate of E+ single lambs was significantly greater than the E- single lambs. There were no significant differences in pre-lamb liveweight of the single-bearing ewes between the E+ and E- groups. It is not known why lamb growth rate was higher in the E+ single lambs in this year. The sample size was small, however.

Pre-lambing liveweights of both the single and twinbearing ewes were significantly lower in the E+ than in the E- group in 1998 and this may have contributed to the lower lamb growth rates. Lower pre-lamb liveweight and greater weight loss during lactation in the E+ ewes during 1998 may have contributed to a difference in milk production.

Data collected in 1998 showed that the differences in lamb growth rate between the E+ and E- groups, and twin and single lambs diminished as the lambs became more dependant on pasture (9-17 weeks old). This evidence supports the hypothesis that differences in lamb growth between E+ and E- groups during the first eight weeks of life may be associated with milk production.

The pre-lambing liveweight and weight-change during lactation of the twin-bearing ewes in the E+ and E- groups were not significantly different between 1997 and 1998. Therefore, the fact that a difference in the growth rate of twin lambs was only evident in 1998 may have been due to significantly higher endophyte toxin levels in the E+ pasture in spring 1998 compared with 1997.

\section{Conclusions}

Grazing endophyte-infected perennial ryegrass pasture significantly reduced the liveweight performance of ewes in this trial. Differences in ewe liveweight occurred when pasture allowance was the same for each group, and thus a reduction in voluntary feed intake by the E+ ewes (indicated by higher post-grazing residues) may have been implicated.

Endophyte toxin levels in the E+ pasture in this trial were not high enough to directly affect ewe fertility. However, under conditions where ryegrass pastures are stressed such as by drought, or where nitrogen levels are high, the toxin levels can be much higher and could be sufficient to affect fertility.

The growth rate of single and twin lambs suckling ewes grazing E+ pasture was reduced in 1998 compared to lambs suckling ewes grazing E- pasture. Differences in lamb growth rate, in particular single lambs, between the E+ and E- groups are likely to be a reflection of milk production differences by the ewes.

Long-term depression of liveweight due to grazing $\mathrm{E}+$ pasture is likely to reduce the lifetime reproductive performance of the ewe.

\section{REFERENCES}

Barker, D.J.; Davies, E.; Lane, G.A.; Latch, G.C.M.; Nott, H.M.; Tapper, B.A. 1993. Effect of water deficit on alkaloid concentrations in perennial ryegrass endophyte associations. pp. 67-71. In: Proceedings of the Second International Symposium on Acremonium/Grass Interactions.

Blythe, L.L.; Tor-Agbidye, J.; Craig, A.M. 1993. Correlation of quantities of lolitrem B toxin to clinical field cases of ryegrass staggers. New Zealand Veterinary Journal 41: 4, 217.

Eerens, J.P.J.; Miller, K.B.; White, J.G.H.; Easton, H.S.; Lucas, R.J. 1994. Ryegrass endophyte and sheep reproduction. Proceedings of the New Zealand Grassland Association 56: 255-258.

Edwards, G.R.; Lucas, R.J.; Johnson, M.R. 1993. Grazing preference for pasture species by sheep is affected by endophyte and nitrogen fertility. Proceedings of the New Zealand Grassland Association 55: 137-141.

Fletcher, L.R.; Sutherland, B.L.; Fletcher, C.G. 1999. The impact of endophyte on the health and productivity of sheep grazing ryegrass-based pastures. Ryegrass endophyte: an essential New Zealand symbiosis. Grassland Research and Practice Series No. 7: 11-17.

Knight, T.N. 1990. Reproductive wastage, a guide for fundamental research: A New Zealand perspective. pp. 8-17 In: Reproductive Physiology of merino sheep: concepts and consequences. Eds. Oldham, C.M.; Martin, G.B.; Purvis, I.W. University of Western Australia.

Kramer, R.; Keogh, R.G.; McDonald, M.F. 1999. Effects of ergovaline in endophyte-infected tall fescue on ewe fertility. Proceedings of the New Zealand Society of Animal Production 59: 263-265.

Lane, G.A.; Tapper, B.A.; Davies, E.; Christensen, M.J.; Latch, G.C.M. 1997. Occurrence of extreme alkaloid levels in endophyte-infected perennial ryegrass, tall fescue, and meadow fescue. pp. 433-436. In: Neotyphodium/Grass Interactions. Eds. Bacon, C.W.; Hill, N.S. Plenum Press, New York \& London. 
Oliver, J.W. 1997. Physiological manifestations of endophyte toxicosis. pp. 311-346. In: Neotyphodium/Grass Interactions. Eds. Bacon, C.W.; Hill, N.S. Plenum Press, New York \& London.

Rowan, D.D.; Tapper, B.A.; Sergejew, N.L.; Latch, G.C.M. 1990. Ergopeptine alkaloids in endophyteinfected ryegrass and fescues in New Zealand. pp. 97-99. In: Proceedings of the International Symposium on Acremonium/Grass Interactions.

Smith, J.F. 1998. Seasonal factors influencing reproductive management. Reproductive management of grazing ruminants in New Zealand. New Zealand Society of Animal Production Occasional Publication No. 12: 65-76. 